\title{
Purchasing power parity in South East Asian countries economies: a cointegration approach
}

\begin{abstract}
This paper presents findings from a study of the long-run purchasing power parity (PPP) conditions in five Asian economies. The cointegration tests using exchange rates and price indices from end-of-quarter observations over the last twenty years reject the PPP proposition for all countries. The absolute version of the PPP hypothesis is tested next by using lower frequency, that is, semi-annual and annual, data. In general these tests also failed to support the long-run PPP hypothesis. Further analysis using the Johansen-Juselius (1990) multivariate approach also failed to support the hypothesis.
\end{abstract}

Keyword: Purchasing power parity (PPP); Asia 